Class Work 



\section{Class Work}

Vocational Schools and China's Urban Youth

T. E. Woronov 
Stanford University Press

Stanford, California

(C) 2016 by the Board of Trustees of the Leland Stanford Junior University. All rights reserved.

No part of this book may be reproduced or transmitted in any form or by any means, electronic or mechanical, including photocopying and recording, or in any information storage or retrieval system without the prior written permission of Stanford University Press.

Printed in the United States of America on acid-free, archival-quality paper

Library of Congress Cataloging-in-Publication Data

Woronov, T. E. (Terry Ellen), author.

Class work : vocational schools and China's urban youth / T. E. Woronov. pages $\mathrm{cm}$

Includes bibliographical references and index.

ISBN 978-0-8047-9541-8 (cloth : alk. paper)-ISBN 978-0-8047-9692-7 (pbk. : alk. paper)

1. Vocational education-China. 2. Vocational school students-China. 3. Urban youthEducation-Social aspects—China. 4. Educational sociology—China. I. Title.

LC1047.C6W67 2015

$370.1130951-\mathrm{dc} 23$

2015011165

ISBN 978-0-8047-9693-4 (electronic)

Typeset by Bruce Lundquist in 10/14 Minion 